\title{
ECONOMIC EVALUATION OF POWER WAVES AT THE BEACH TEGAL
}

\author{
SOEBYAKTO \\ Faculty of Engineering, Pancasakti University of Tegal \\ Email: soebyakto@gmail.com
}

\begin{abstract}
ABSTRAK
Pengamatan terhadap listrik tenaga di Pantai Tegal diperoleh dengan menemukan nilai kecepatan, frekuensi dan ketinggian ombak di pantai Tegal. Nilai rata-rata kecepatan gelombang 0,15 m / s, frekuensi rata-rata $0,17 \mathrm{~Hz}$ dan tinggi maksimum $0,6 \mathrm{~m}$ rata-rata. Data ini masih terlalu rendah untuk menghasilkan tenaga listrik dari tenaga mekanik ombak. Guna meningkatkan kecepatan dan tinggi ombak dengan metode "Tapered Channel" saat ini sedang tahap riset lanjutan. Metode ini diharapkan dapat meningkatkan nilai tinggi gelombang $0,5 \mathrm{~m}$ sampai 2,2 $\mathrm{m}$. Gelombang listrik diperkirakan naik menjadi 15,4 Watt / $\mathrm{m}^{2} 25-50$ Watt / m2. Dalam perhitungan ekonomi, kekuatan ombak mulai dari nilai daya gelombang per $\mathrm{m}^{2}$ per 4 $\mathrm{m}^{2}$. Jika kita membutuhkan kekuatan 100 Watt ombak, area pantai yang dibutuhkan $4 \mathrm{~m}^{2}$. Pembangunan ekonomi pantai dengan ombak menghasilkan tenaga listrik, dibangun di luar kawasan pelabuhan, sehingga nelayan tetap melakukan usaha perikanan sebagaimana mestinya. Berdasarkan hasil penelitian secara teori, kekuatan gelombang adalah kecepatan fungsi gelombang yang menggambarkan kurva linier. Namun, hasil penelitian yang telah dilakukan menunjukkan bahwa kekuatan ombak adalah fungsi kecepatan ombak yang digambarkan sebagai kurva hiperbolik. Daya gelombang meningkat dengan meningkatnya kecepatan ombak. Sedangkan formulasi yang digunakan adalah kecepatan gelombang adalah fungsi tinggi gelombang. Dengan menggunakan metode "Tepered Channel" untuk menangkap gelombang, kecepatan gelombang akan semakin tinggi. Hasil penelitian ekonomi untuk menghasilkan gelombang listrik dapat dihitung dengan aspek ekonomi daya komputasi dari gelombang dan aspek teknologi dengan menghitung frekuensi gelombang.
\end{abstract}

Kata Kunci: Konsep ekonomi biru pada daerah pantai; Tenaga ombak di pantai; Tenaga listrik dari gelombang laut.

\begin{abstract}
Observations of electric power of the waves hitting beach Tegal is obtained by finding the value of the speed, frequency and height of the waves on the beach Tegal. The average value of the wave velocity of $0.15 \mathrm{~m} / \mathrm{s}$, the average frequency of $0.17 \mathrm{~Hz}$ and a maximum height of $0.6 \mathrm{~m}$ on average. This data is still too low to generate electrical power from the mechanical power of the waves. We are still conducting research to increase the speed and height of the waves with a method of "Tapered Channel". This method is expected to raise the value of the wave height of $0.5 \mathrm{~m}$ to $2.2 \mathrm{~m}$. Waves of electrical power is estimated to rise to $15.4 \mathrm{Watt} / \mathrm{m}^{2} 25-50 \mathrm{Watt} / \mathrm{m}^{2}$.In economic calculation, the power of the waves starting from the value of the wave power per $\mathrm{m}^{2}$ per $4 \mathrm{~m}^{2}$. If we need a 100 Watt power of the waves, the beach area that required $4 \mathrm{~m}^{2}$. Economic development beach with waves generate electrical power, built outside the port area, so that the fishermen keep doing the fishing business as it should be. Based on the results of research in theory, the power of the waves is the speed of the wave function that describes the linear curve. However, the results of research that has been done show that the power of the waves is a function of the speed of the waves, which described as a hyperbolic curve. Wave power increases with increasing speed of the waves. While the formulation used is the wave velocity is a function of the height of the waves. By using the method of "Tepered Channel" to catch a wave, the wave speed will be higher. The results of economic research to generate electrical waves can be calculated byeconomic aspects of the compute power of the waves and technological aspects by counting the frequency of the waves.
\end{abstract}

Keywords: Blue economic concept on the area of beach; Electric power from wave of sea; Wave power on beach. 


\section{INTRODUCTION}

In the beginning, we are interested in the economic development of the concept of the blue coastal regions because this area consists of land and Ocean Beach. There are natural phenomena that occur in the sea i.e. The energy waves reach the coast and windy. The wind is blowing from the land out to sea at night and the wind blows from the sea to the land during the day. The wind blows from high pressure to low pressure. Ocean surface waves is influenced by surface wind. Research has been carried out and focused on shallow water waves in coastal areas. The purpose of this study is to know the power of the waves to the shore. These data is used to calculate the electrical power generated from waves of mechanical power. Research findings in the form of electric power value of ocean waves, were evaluated to obtain the blue economy concept in coastal areas.

\section{Methode \\ Place and time of study}

The first study to obtain data waves on the beach Tegal was conducted from June - September 2010 during the hours 11:00 to 13:00 $\mathrm{pm}$. The second study at the beach Tegal was conducted in Friday, July 13, 2012 at 14:25 to 15:30 pm. The third was conducted on Friday, dated March 1, 2013 at 16:00 to 16:30 pm.

\section{Frequency and Height of the waves}

The first time, we define a point on the sea coast, which is a representative conditions for calculating the frequency and wave height. At that point,

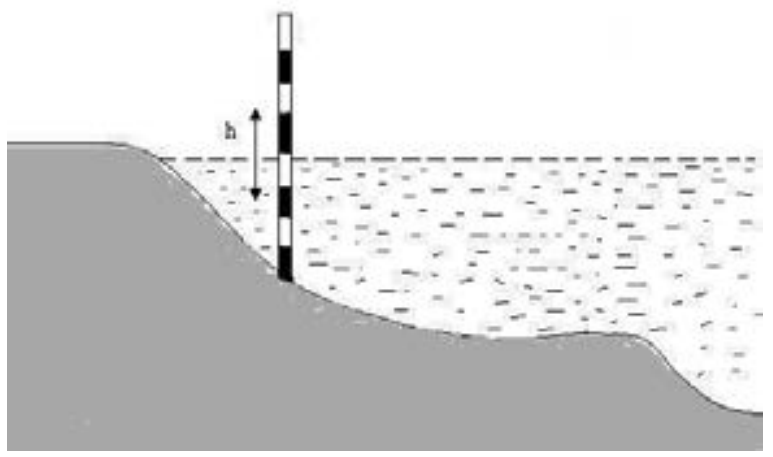

Figure 1. Placed Piles Centimeter Scale.
Setting up a stopwatch, a pen and study worksheets to record the height and frequency of waves. By using the equation:

$$
f=\frac{\mathrm{n}}{\mathrm{t}}
$$

Where: $\mathrm{n}=$ number of waves $\mathrm{t}=$ duration of the waves at one point (s)

$\mathrm{f}=$ the frequency of waves $(\mathrm{Hz})$.

To change the unit of Hertz became a Rotation Per Menitues: 1 second =1/60 minutes

$$
\begin{aligned}
f= & \frac{\mathbf{n}}{\mathbf{t}} \times 60 \mathrm{rpm} \\
H & =H_{\text {maks }}-H_{\text {min }} \\
& \text { where : } \\
f \quad & =\text { frequency waves }(\mathrm{Hz}) \\
H \quad & =\text { wave height }(\mathrm{m}) \\
H_{\text {maks }} & =\text { peak wave height }(\mathrm{m}) \\
H_{\text {min }} & =\text { height of wave valley }(\mathrm{m})
\end{aligned}
$$

\section{Speed of Waves}

Measurement of wave velocity (v), there are two types of wave speed that moves vertically and horizontally. The rate of vertical wave done by recording the number of wave in a given time interval and amplitude of wave at one point scale piles. The rate of the waves horizontally by measuring the number of waves on a specific time interval and amplitudonya on two points of scale piles. For shallow water, wave speed can also be obtained by measuring the $h$ (the depth of the sea waters where wave propagates). Wave speed calculated using the equation: $\mathrm{v}=\sqrt{ } g h$, where $\mathrm{g}$ is the gravitational acceleration of the Earth. Determine the speed of the waves at one point, we call vertical speed: $v=2 \pi f h$

\section{Wave Power}

Energy (perunit area) of a sinusoidal wave depends on the density $\rho$, the gravitational acceleration $g$ and the wave height $\mathrm{H}$ (which is equal to twice the amplitude, a):

$$
\mathrm{E}=1 / 8 \rho g \mathrm{H}^{2}=1 / 2 \rho \operatorname{\rho g}^{2}
$$

For shallow waters, comparisons h (depth) by $\lambda$ (sea wavelength), $\frac{h}{\lambda}<\frac{1}{20}$; the power per square meter of wavefront: 
$\mathrm{E}=1 / 8 \rho \mathrm{\rho H}^{2} \mathrm{v}$

$\mathrm{P}=$ wave power $\left(\mathrm{W} / \mathrm{m}^{2}\right)$

\section{Tapered Channel}

Waves coming at the entrance "tapered channel", fulfilling the law of conservation of mass.

$\Sigma$ incoming water masses $=\Sigma$ water mass exit
$\rho=\frac{m}{V} \rightarrow \mathrm{m}=\rho . \mathrm{V}$

$\mathrm{V}=\mathrm{A} \cdot \mathrm{h}$

$\mathrm{A}=\mathrm{X} . \mathrm{Y}$

$\rho=$ the density of liquid $\left(\mathrm{kg} / \mathrm{m}^{3}\right), \mathrm{m}=$ liquid mass $(\mathrm{kg})$,

$\mathrm{V}=$ liquid volume $\left(\mathrm{m}^{3}\right)$.

$\mathrm{A}=$ cross-sectional area $=$ length $(\mathrm{X})$ times width $(\mathrm{Y})$ "tapered channel" $\left(\mathrm{m}^{2}\right), \mathrm{h}=$ wave height $(\mathrm{m})$.

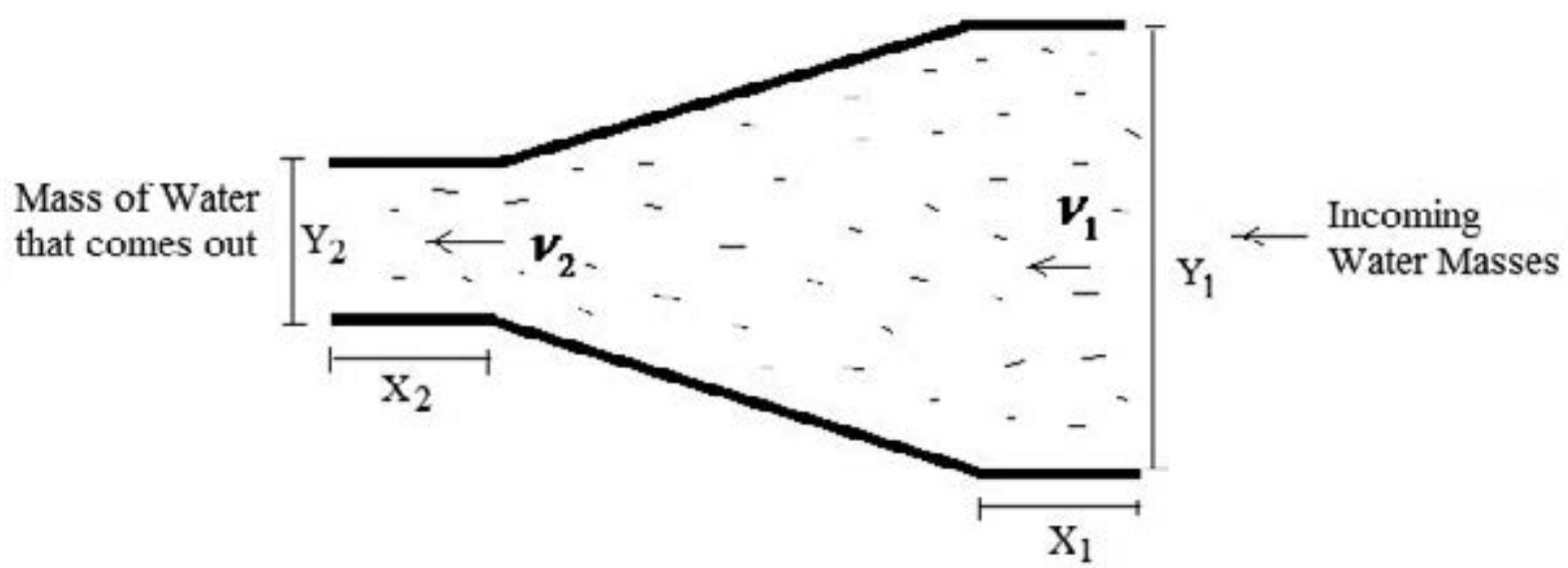

Figure 2. Tapered Channel

\section{RESULTS AND DISCUSSION}

Economic evaluation of electric power using a shallow water wave formulation:

$$
P=\frac{1}{8} \rho g H^{2} \sqrt{g h}=\frac{1}{8} \rho g H^{2} v
$$

where :

$H=$ wave height $(\mathrm{m})$

$h=$ depths of ocean waters (m).

Assumptions : $\rho=1026 \mathrm{~kg} / \mathrm{m}^{3}, g=9.81 \mathrm{~m} / \mathrm{s}^{2}$, $1 \mathrm{kWh}=\mathrm{Rp} .793$; if the cost of usage per day 8 hours, then to 240 hours a month, so the cost of 1 month of use $1 \mathrm{kWh}$ of Rp. 190320.
Calculation of wave energy usage fee per month, using the formula:

$$
\begin{aligned}
P & =\frac{W}{t} \\
\mathrm{~W} & =\text { P.t }
\end{aligned}
$$

where :

$\mathrm{P}=$ wave power $(\mathrm{kW})$

$\mathrm{t}=$ time usage (hours)

$\mathrm{W}=$ wave energy $(\mathrm{kWh})$ 
Table 1

Wave Energy Consumption Cost perMonth

\begin{tabular}{|c|c|c|c|c|}
\hline $\mathrm{Nu}$. & $H(\mathrm{~m})$ & $v(\mathrm{~m} / \mathrm{s})$ & $P(\mathrm{~kW} / \mathrm{km})$ & Cost of sales per month \\
\hline 1 & 0.3 & 0.2 & 22.6 & $\operatorname{Rp} 4,310,059.99$ \\
\hline 2 & 0.4 & 0.3 & 60.4 & Rp 11,493,493.32 \\
\hline 3 & 0.5 & 1.2 & 377.4 & Rp 71,834,333.22 \\
\hline 4 & 1 & 1.5 & 1887.2 & $\operatorname{Rp} 359,171,666.10$ \\
\hline 5 & 1.5 & 2 & 5661.6 & $\operatorname{Rp} 1,077,514,998.30$ \\
\hline 6 & 2 & 2.5 & 12581.3 & $\operatorname{Rp} 2,394,477,774.00$ \\
\hline 7 & 3 & 3 & 33969.6 & $\operatorname{Rp} 6,465,089,989.80$ \\
\hline
\end{tabular}

For ocean areas with an area of 1 square kilometer, if we take the assumption of no state grain waves. 1 in Table 5.1, the energy of ocean waves to generate electricity:

$$
P=22.6 \mathrm{~kW} / \mathrm{km}
$$

If a set of wave power plant to cost Rp. $5,000,000.00$ (five million dollars), then for 1000 sets of wave power plant will cost Rp.
5,000,000,000.00 (five billion rupiahs). While the selling price per $1 \mathrm{kWh}$ electricity is Rp. 793.00 (seven hundred and thirty three rupiahs). Thus in point 1 Table 5.1, the selling price of electrical energy of $22.6 \mathrm{~kW} / \mathrm{km}$ multiplied by Rp. 793.00, has a sale value per hour is Rp. $17921.8 \mathrm{kWh} / \mathrm{km}$. If the daily electrical energy consumption an average of 8 hours, then for one month is $\operatorname{Rp} 4,310,059.99$. For the year amounted to Rp. 51,614,784.00.

Table 2

Sales Price Wave Energy Use by Theory of Oceanography

\begin{tabular}{|c|c|c|c|c|c|c|c|}
\hline NO. & H (m) & E & $\mathrm{v}(\mathrm{m} / \mathrm{s})$ & $P(\mathbf{k W} / \mathbf{k m})$ & Making prices & Selling price / year & $\mathbf{N}$ (year) \\
\hline 1 & 0.3 & 113.2 & 0.2 & 22.6 & Rp 5,000,000,000 & Rp 51,614,784 & 96.87 \\
\hline 2 & 0.4 & 201.3 & 0.3 & 60.4 & Rp 5,000,000,000 & $\operatorname{Rp} 137,943,936$ & 36.25 \\
\hline 3 & 0.5 & 314.5 & 1.2 & 377.4 & Rp 5,000,000,000 & $\operatorname{Rp} 861,921,216$ & 5.80 \\
\hline 4 & 1 & 1258.1 & 1.5 & 1887.2 & Rp 5,000,000,000 & Rp 4,310,062,848 & 1.16 \\
\hline 5 & 1.5 & 2830.8 & 2 & 5661.6 & $\operatorname{Rp} 5,000,000,000$ & $\operatorname{Rp} 12,930,188,544$ & 0.39 \\
\hline 6 & 2 & 5032.5 & 2.5 & 12581.3 & $\operatorname{Rp} 5,000,000,000$ & $\operatorname{Rp} 28,733,676,192$ & \\
\hline 7 & 3 & 11323.2 & 3 & 33969.6 & Rp 5,000,000,000 & $\operatorname{Rp} 77,581,131,264$ & \\
\hline
\end{tabular}

In Table 1 obtained in item 1-3. wave height $0.3 \mathrm{~m}-0.5 \mathrm{~m}$. If this study used methods tapered channel, the data obtained in Table 4, from a height of $0.5 \mathrm{~m}$ to $2.2 \mathrm{~m}$ height. We note that the power generated in Table 3 .

Tabel 3

The power generated

\begin{tabular}{l|l|l|l|l|l}
\hline \multicolumn{1}{c|}{$\mathbf{H}(\mathbf{m})$} & \multicolumn{1}{c|}{$\boldsymbol{v ( \mathbf { m } / \mathbf { s } )}$} & $\boldsymbol{P}(\mathbf{k W} / \mathbf{k m})$ & \multicolumn{1}{c}{ Making prices } & \multicolumn{1}{c}{ Selling price /year } & \multicolumn{1}{c}{$\mathbf{N}($ year) } \\
\hline 1 & 1.5 & 1887.2 & $\operatorname{Rp} 5,000,000,000$ & $\operatorname{Rp} 4,310,062,848$ & 1.16 \\
\hline 1.5 & 2 & 5661.6 & $\operatorname{Rp} 5,000,000,000$ & $\operatorname{Rp} 12,930,188,544$ & 0.39 \\
\hline 2 & 2.5 & 12581.3 & $\operatorname{Rp} 5,000,000,000$ & $\operatorname{Rp} 28,733,676,192$ & \\
\hline
\end{tabular}


Tabel 4

Wave Height Data Estimates Using Tapered Channel

\begin{tabular}{l|l|l|l|l|l|l}
\hline \multicolumn{1}{c|}{$\mathbf{N O}$} & \multicolumn{1}{|c|}{$\mathbf{X}_{\mathbf{1}}(\mathbf{m})$} & $\mathbf{Y}_{\mathbf{1}}(\mathbf{m})$ & \multicolumn{1}{c}{$\mathbf{H}_{\mathbf{1}}(\mathbf{m})$} & $\mathbf{X}_{2}(\mathbf{m})$ & $\mathbf{Y}_{2}(\mathbf{m})$ & $\mathbf{H}_{\mathbf{2}}(\mathbf{m})$ \\
\hline 1 & 0.5 & 2 & 0.55 & 0.5 & 0.5 & 2.2 \\
\hline 2 & 0.5 & 2 & 0.54 & 0.5 & 0.5 & 2.2 \\
\hline 3 & 0.5 & 2 & 0.62 & 0.5 & 0.5 & 2.5 \\
\hline 4 & 0.5 & 2 & 0.49 & 0.5 & 0.5 & 2.0 \\
\hline 5 & 0.5 & 2 & 0.58 & 0.5 & 0.5 & 2.3 \\
\hline 6 & 0.5 & 2 & 0.64 & 0.5 & 0.5 & 2.6 \\
\hline 7 & 0.5 & 2 & 0.65 & 0.5 & 0.5 & 2.6 \\
\hline 8 & 0.5 & 2 & 0.7 & 0.5 & 0.5 & 2.8 \\
\hline & & & 0.6 & & & 2.4 \\
\hline
\end{tabular}

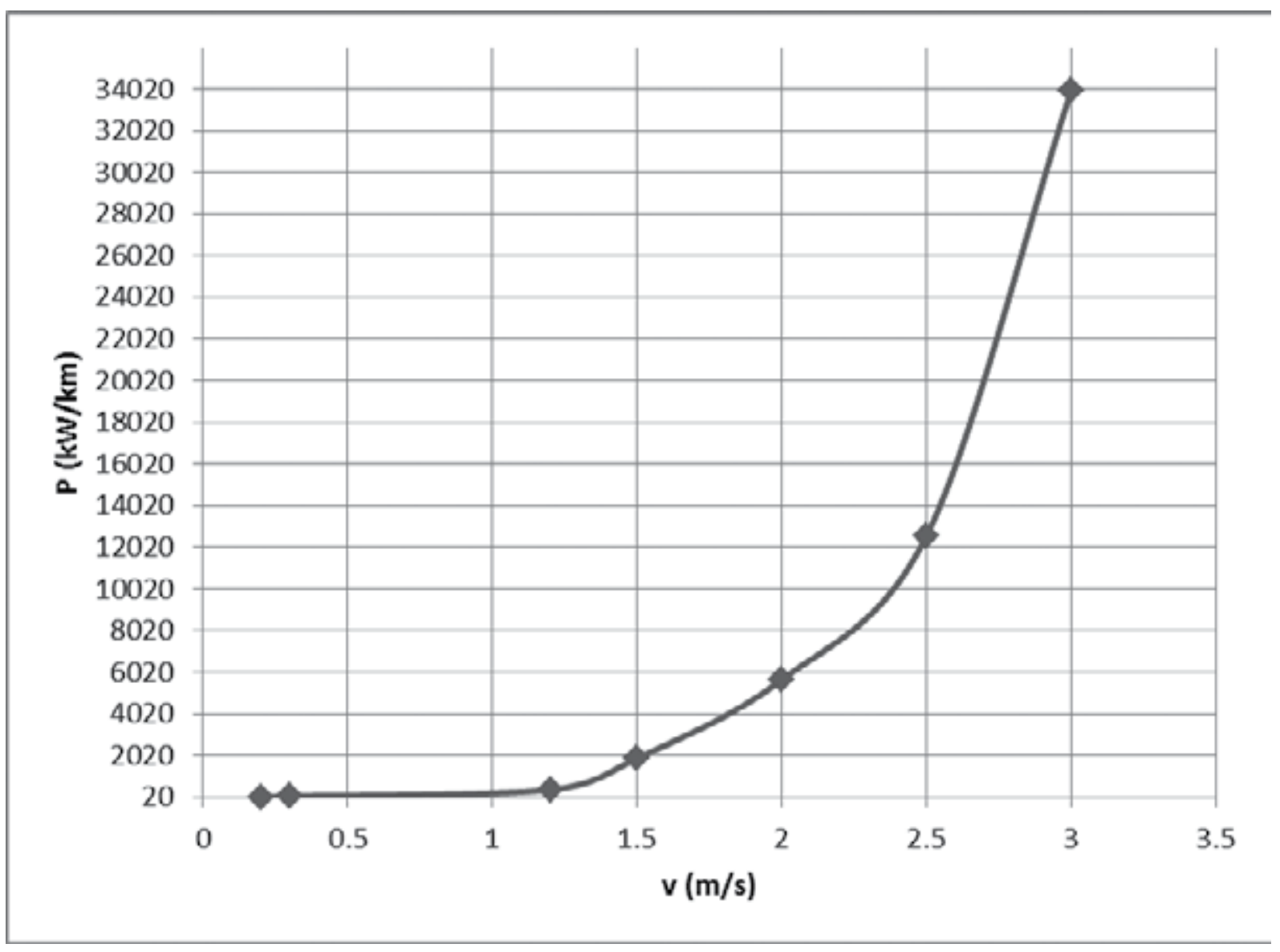

Figure 3

\section{CONCLUSION}

The power of wave is a linear function of wave speed. This research shows that the power of wave is a hyperbolic curve. This means following the formulation of wind power which is a function of the cube of the wind speed. Two factors are used in the economic evaluation and technology. The power and frequency of waves on coastal area. These two parameters will be used in planning tool of wave energy conversion into electrical energy. 
Based on the concept of mathematics and physics calculations using a Tapered Channel, wave height is expected to change from 0.5 $\mathrm{m}$ become $2.2 \mathrm{~m}$. Electrical energy can be obtained from ocean wave energy with the provisions, the power and frequency of the waves can drive the dynamo with rpm (rotations per minute) which is sufficient to obtain electricity.

\section{BIBLIOGRAPHY}

Eko Sarjono. 2012. "Pembangkit Listrik Tenaga Ombak". <http://www.alpensteel. com/article/51-113-energi-lainlain/161--pembangkit-listriktenaga-ombak-dikembangkan. html >[29/02/2012 21:24].

Gunawan. T. 2008. Pemanfaatan Energi Laut 1: Ombak. Majari Magazine. <http:// majarimagazine.com/> [27/02/2010 15:55].

Riyadi. A.. 2010. Gelombang Laut Berpotensi Sebagai Energi Listrik. <http://www. alpensteel.com/article/52-106-energilaut ombakgelombangarus/2181-gelombang-laut-berpotensi-sebagaienergi-listrik.html> [14/03/2010 08:29].

Rahmanta. 2010. Metode Konversi Gelombang Laut. Ocean Wave Energy. <http:// www.begokmild.com> $[21 / 11 / 2010$ 17:05].

Rwahyuningrum. 2009. Energi Gelombang Laut. <http:/ / rwahyuningrum.blog.uns. ac.id/2009/08/25/energi-gelombanglaut/> [04/02/2011 18:17].

Sutrisno. 1977. Fisika Dasar. Mekanika Jilid 1. Bandung : Penerbit ITB.

Oxana. 2010. Daftar Kenaikan Tarif listrik per 1 juli 2010. <http://oxana.blogdetik. com/2010/06/16/ daftar-kenaikantarif-listrik-per-1-juli-2010/> [21/11/2010 12:35].

Wikimedia. 2010. Analisis Regresi. Wikimedia Foundation. Inc. 